\title{
The quality of education: a reflection from the pedagogical academic management
}

\section{La calidad de la educación: una reflexión desde la gestión académica pedagógica}

DOI: http://dx.doi.org/10.17981/cultedusoc.11.1.2020.15

Recibido: 30/11/2019. Aceptado: 19/02/2020. Publicado: 24/03/2020

Oscar Alberto Peláez Henao

Universidad Católica Luis Amigó. Medellín (Colombia)

oscar.pelaezhe@amigo.edu.co

Adriana María Gallego Henao

Universidad Católica Luis Amigó. Medellín (Colombia)

maestria.educacion@amigo.edu.co

Roger Alexander González Ramírez

Universidad Católica Luis Amigó. Medellín (Colombia) nisaro15@gmail.com

Para citar este artículo:

Peláez, Gallego y González. (2020). The quality of education: a reflection from the pedagogical academic management. Cultura, Educación y Sociedad, 11(1). 209-218. DOI: http://dx.doi.org/10.17981/cultedusoc.11.1.2020.15

\section{Abstract}

The purpose of the research is to recognize the impact of pedagogical academic management on the educational quality of school organizations in the municipality of Santa Rosa de Osos (Medellín, Colombia) and whose findings contribute knowledge to improve pedagogical and teaching-learning processes. The paradigm is historical-hemeneutic of qualitative type, and as a research strategy the case study is privileged. In this order of ideas, academic and pedagogical processes are related to the quality of the educational institutions studied. It is expected in the immediate future to integrate the results in the reformulation of projects, policies and programs that seek to improve the quality of education.

Keywords: Educational quality; pedagogical academic management; education

\section{Resumen}

La investigación tiene como propósito reconocer la incidencia de la gestión académica pedagógica en la calidad educativa de las organizaciones escolares del municipio de Santa Rosa de Osos (Medellín, Colombia) y cuyos hallazgos aporten conocimientos para mejorar los procesos pedagógicos y de enseñanza- aprendizaje. El paradigma es histórico-hermenéutico de tipo cualitativo, y como estrategia de investigación se privilegia el estudio de caso. En este orden de ideas se relacionan los procesos académicos y pedagógicos con la calidad de las instituciones educativas estudiadas. Se espera en un futuro inmediato integrar los resultados en la reformulación de proyectos, políticas y programas que busquen mejorar la calidad educativa.

Palabras clave: Calidad educativa; gestión académico pedagógica; educación 


\section{INTRODUCTION}

Getting closer to the school, to its dynamics, to the people who inhabit it, to the spaces it occupies and to its history, implies returning to the principles, guidelines, purposes and tasks that society has historically endowed to this institution. That is, to return to the foundations that support the didactic and pedagogical exercise of the teachers, to take up the motivations of the students and, of course, the necessary conditions to achieve the altruistic and sometimes even utopian goals that has been associated with the school action.

During the mid-20 ${ }^{\text {th }}$ century, the French sociologist Pierre Bourdieu coined the concept of Cultural Capital, which today can be understood as the set of advances, customs, ethical positions and knowledge. Our society safeguards this cultural capital as part of its heritage that has chosen to preserve and share. But to a large extent, this task has been left to the school. And, the school, as an institution has widely regulated it, parameterized it and shaped it to levels, grades, spaces and titles.

In this scenario, it is essential to understand what tools and strategies the school has chosen to fulfill the task of training in the cultural capital of a social group. Doing so involves reflection on three fundamental aspects: The teacher, understood as the craftsman; the context, assumed as the space of interaction; and the curriculum as the concrete manifestation of the cultural capital. It is from the interaction of these elements that school education emanates and it is with these elements that the triad composed of pedagogydidactics-research is related and complements.

Now, reflecing on the educational processes in terms of quality and its connections to the academic pedagogical management, is a space with many possibilities in the municipality of Santa Rosa de Osos (Medellín, Antioquia), the above considering that in this municipality are few studies that have been made in favor of understanding the relations between quality and educational management. Therefore, the study intends a comprehension of quality as a concept framed under the pedagogical management and how it relates with the educational institutions as they seek for quality. In addition, it aims at providing a horizon of meaning that allows how pedagogical practices and teaching in institutions contribute to improve education policies in the municipality and in possible recommendations enhancing institutional quality.

In this order of ideas, understanding quality as a dynamic process and one of which each of the characters of the school milieu has something to say, something to contribute or a horizon towards which to run, implies building from the dialogue of knowledge. It also implies to add to the discussions the points of view of all and from there on to build the reference lines associated with the concept of quality, the aspects to consider and the questions that support the reflection of teachers.

There has not been a research initiative that raises the need to review the appropriation and practice of academic and pedagogical management of educational institutions in Santa Rosa de Osos. This becomes an opportunity to visualize quality processes in Education; Additionally, this process integrates the educational community in its development. Summing up, this paper is the partial result of the investigation, the academic-pedagogical management as a strategy that contributes to the comprehension of the educational quality of the educational Institutions of the municipality of Santa Rosa de Osos. 


\section{Methodology}

Considering the purpose of education and the process and conditions for achieving them, this research investigates and reflects on the initiatives of educational establishments that are in coherence with the academic pedagogical management. Therefore, this project is based on the need to know the conceptions, associated practices and achievements of the management of teachers and principals and how they relate to the quality of education of the educational institutions participating in the study. The purpose of the afore mentioned is to support and propose guidelines that contribute to improving educational management, consistent with the needs of the context, the students, and the resources administered by the institution, emphasizing that the role of the educational community should play a decisive role in the elaboration of the proposals, in the discussion, and in the definition of priorities in the school setting that strengthen and contribute to the improvements and achievement of quality.

\section{Paradigm and Approach}

This research was carried out under a qualitative paradigm and a hermeneutical approach. The research strategy assumed was a case study, as it allowed recognizing the relationship between quality and academic-pedagogical management from the voices of the participants.

\section{Participants}

The participants selected for the research were teachers from two Educational Institutions in the municipality of Santa Rosa de Osos (Medellín, Antioquia). The criteria established to select them were: Teachers from public institutions, one rural and the other Urban; one dedicated to formal education and the other enrolled in non-formal training and for work. The teachers who participated in the study were 12 , six from each Institution.

\section{Data gathering techniques}

The data collection techniques that were privileged in the study were: 12 semi-structured interviews. One interview to each participant. Two discussion groups, one in each educational institution.

\section{Techniques for information analysis}

The analysis of the data was carried out in three stages. First, the codification of the testimonies; second, the classification by categories of analysis; and third, the contrast with the theoretical reference of the research. Then we proceeded to the construction of the analyzes by means of discussion and interpretations done by the researchers, procedure that allowed the development of this manuscript. 


\section{Findings And Discussion}

\section{Conceptual perspectives of educational management ant its relation to quality}

The relationship between management and education can be exemplified through different authors. For Lusquiños (2005), management "refers to a process of complex articulation of attitudes, aptitudes, interests and general capacity of the members for the systematic turning of decisions and concretion of actions until the achievement of results" (p. 81). According to International Institute for Education Planning and United Nations Educational, Scientific, and Cultural Organization (IIEP \& UNESCO, 2000), is consists of processes based on theory and experience, integrated in vertical and horizontal dimensions to respond to the demands of the society. Educational management "is a knowledge of synthesis capable of linking knowledge and action, ethics and effectiveness, policies and administration in processes that tend to the continuous improvement of educational practices" (Martínez, 2012, p. 16).

It is important to note that Educational Management seeks the articulation of academic processes in the Institution which becomes an opportunity so the school be able to think itself as entity capable of articulating the pedagogical practices and management with the community. That is precisely the definition given by Martínez (2012):

Ability to generate an appropriate relation between the structure, strategy, systems, leadership style, capabilities, people and higher goals of the considered organization as well as the ability to articulate available resources in a way that achieves what is desired (p. 17).

Therefore, Educational Management appears as the need to systematize human actions within the school space, through vertical and horizontal relations, around common objectives, considering the context and the social, cultural and political demands in which the school nested and that give account of quality. To that respect one of the participant highlights:

Walking towards quality implies the permanent review of what is happening in the class. It is important that the materials, texts and activities are reviewed after each of the sessions; students change, technology is updated. In that respect it is impossible that the teacher and what he does don't change (ES-5).

As the evidence indicates, teaching work is crucial. here it is about configuring spaces for dialogue and reflection on pedagogical practice in the educational institution. these spaces should allow classroom management to be aligned with the purposes of the institution, the school context, the national curriculum and the voice of the community. only from this union can true processes of qualification and improvement emerge. Therefore, the effective realization of these objectives is of the utmost importance.

Thus, educational management also seeks diagnoses that make it possible to reflect on the most efficient and pertinent methods of these human actions in order to favor the fulfillment of the goals that have been configured as a society. Unlike an administrative and bureaucratic paradigm, in which there is a rigid vertically in decision-making and a demarcation between administrative and pedagogical (Pérez-Ruiz, 2014), educational management exalts inherently actions and recognizes their intricacies within the school. 
Educational management should also foster a symbolic relationship between the school and its environment; the different actors (school children, non-school children) must establish synergies that allow teamwork, the fulfillment of common goals, and the consolidation of the ideals, visions and demands that society expects, but at the same time that it interacts with the society and contribute to its transformation.

For this reason, constructions such as the curriculum, the figure of the teacher, and the place of the context in the school process, are understood within the framework of the concept of quality and the practices that account for it. This, not only allows to articulate the work from a methodological perspective, but also, permits to expose the reality of the participants from their testimonies, their tensions around the teaching-learning process and the challenges they assume in terms of naming what they do and venturing themselves into the interpretation of their actions.

\section{The academic teaching management, an opportunity to achieve educational quality}

Similar to the concept of educational management, the subcategories that compose it vary in number and name, depending on the authors or guides. For example, the National Ministry of Education (MEN, 2008) in "La Guía 34 for institutional improvement", includes educational management from four dimensions: Directive management, academic management, administrative and financial management, and the management of coexistence and community. While the Mayor's Office of Medellín (2015) in the "Guide City of Medellín Award for the Quality of Education”, categorizes three dimensions: Directive-administrative management, academic-pedagogical management, and community management. On the other hand, Correa, Álvarez \& Correa (2010) lists 4 dimensions: Directive management, academic management, administrative and financial administration, and coexistence and community management. And finally, in the model of Strategic Educational Management (Quality Schools Program, 2010), 4 dimensions are mentioned: Curricular pedagogical management, organizational management, administrative management, and social participation management.

For the purpose of this study, a model will be taken from "La Guía 34" of the MEN (2008), which establishes the institutional management must account for four areas of management, which are: Management Directive, financial and administrative management, Community management and Academic management. The proposed research focused on academic management:

The essence of work of an educational establishment, because it indicates how its actions are focused to make students learn and develop the skills necessary for their personal, social and professional performance. This area is responsible for managing the processes of curricular design, institutional pedagogical practices, management and monitoring academic classes (MEN, 2008, p. 27).

As noted, this type of management includes the closest relationship between the teacher and the student, since, for the educational context, the teacher is who focuses and directs the actions and curricular didactics in the classroom. He also manages the classes, which must be properly assimilated by the students. 
It is here when the role of the teacher as a guide or monitor plays a vital role within the curricular implementation of the educational institution. His or her task then is to permanently assist learning situations in the classroom and to provide spaces to reflect upon what is happening. Not only that, but also to mediate the conflicts that take place there and to propose various ways to confront them and turn them into opportunities for improvement. Finally, is crucial to manage the necessary actions to promote students learning.

The aforementioned invites us to think that the curricular implementation contravenes the barriers of the classroom and makes the educational institution as a whole responsible for reflecting on the multiple ways that the school has to face the academic proposals. At the same time, calls for a collective responsibility to promote these discussions around of these constructions. Is the teacher, who in addition to knowing them, as he contributes in a solidary way in their planning, is co-responsible for their implementation and therefore for their permanent revision and the possible adaptations.

On the other hand, it is important to highlight that among the tasks that the school faces in regards to the academic management, are those related to the planning, development and qualification processes of school practices. This type of actions is related to the knowledge that transits the school space; the relationships of individuals within it; the knowledge that has been privileged for teaching; as well as the methodological actions to guide them. This set of processes is known as the curriculum. Regarding the above, Sacristán (2007) refers to the curriculum as a construction in which several elements converge:

The curriculum as a confined project in a build and ordered plan relates to the connection between some principles and their realization, something that has to be verified and that in that practical expression is where its value is specified. It is a practice in which a dialogue is established, so to speak, between social agents, technical elements, students who react to it, teachers who model it (p. 16).

In the same context, the curriculum might be understood as the space in which all elements converged: Pedagogical practices, actors' points of view, the different scenarios that relate in the educational institution and that have as main objective the students learning process. This process is at the center of the pedagogical and didactic tasks carried out by teachers, because teachers are in charge of designing, guiding, managing and giving direction the pedagogical practices of their institutions, according to the criteria, purposes and aims of guidelines or principles stablished by policymakers. In this sense a participant added,

As teachers, we have the task of planning and evaluating that planning, it is necessary to periodically review what we propose in the classroom and carefully determine the adjustments; to try to incorporate the things that the students require and the demands derived from the context (GD-S).

As the testimony points out, the task is the permanent action of reflection on the context and on the knowledge that takes relevance for the participation of the students within it; in the words of the participating teachers, this derives to the curricular action. The following graphic based on the scheme proposed by United Nations Educational, Scientific and Cultural Organization (UNESCO, 2005), outlines what is understood in this work by educational quality (Figure 1). 


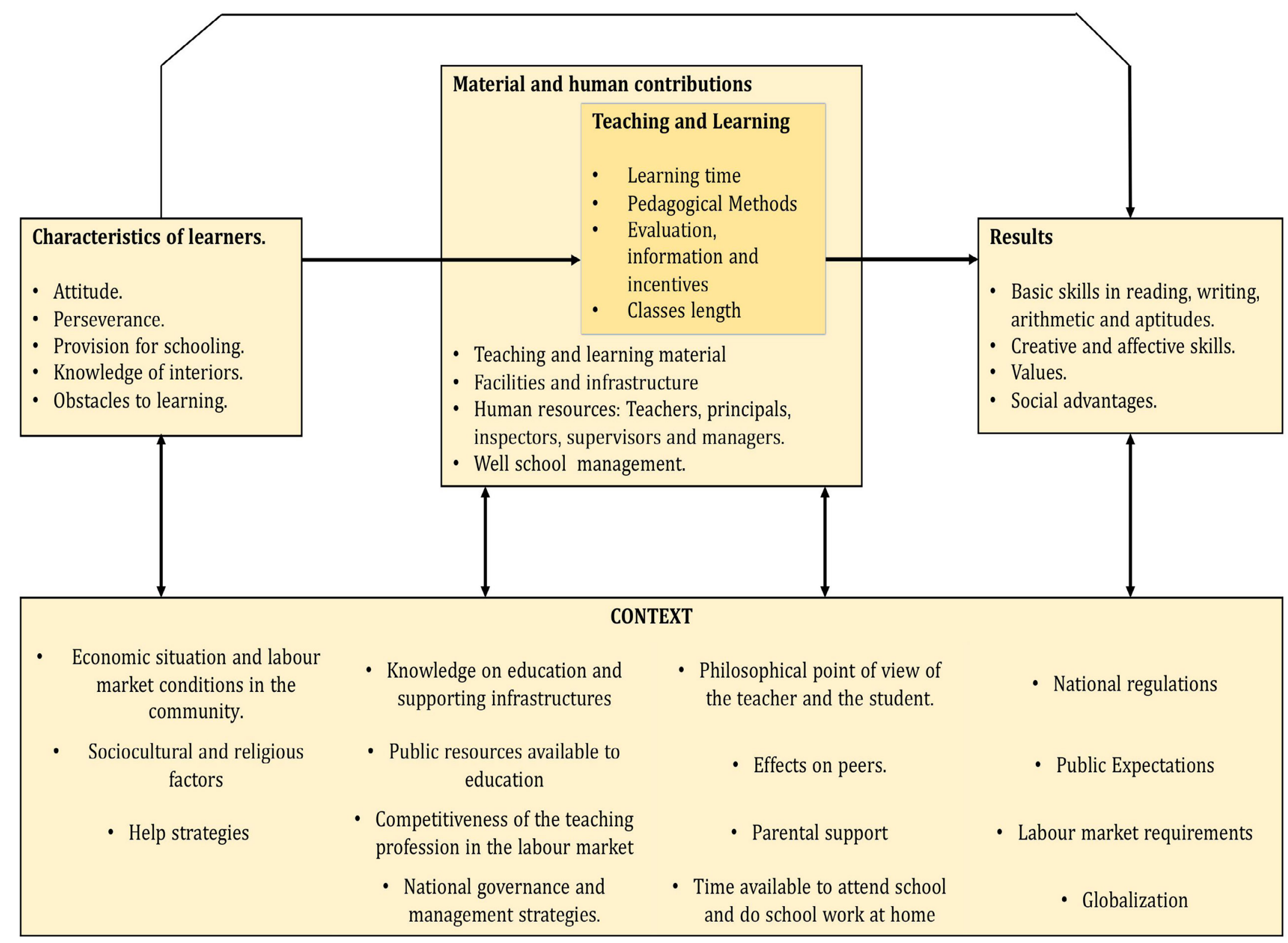

Figure 1. Educational quality Source: UNESCO (2005, p. 7).

Returning to what was stated by the Mayor's Office of Medellín (2013), it assumes the quality of education as "relevant, pertinent, contributing to the construction of more equitable schools, as well as efficient and effective, and responding to the needs and situations of the institutional community that inhabits educational establishments. (...). (p. 12). In this sense the Educational Office of Medellin highlight:

The quality of education is part of a permanent construction in which the achievement of objectives is verified during and at the end of a process, improvements are introduced and institutional goals are reviewed to confirm whether they respond to valid ethical principles for democratic society, guarantor of rights. Therefore, in a quality education, progress is ratified in formative, academic and social results, from an inclusive institutional proposal that recognizes, documents and systematizes its practices in the light of its pedagogical intentionality and its cultural and social contexts (Mayor's Office of Medellín, 2014, p. 12).

Keeping in mind that academic management is responsible for fulfilling the essential mission of an educational institution, having the function of the organization, distribution and appropriation of knowledge in context, as a result of the significant learning that must 
be understood by the students to be protagonist of the construction of life project and it will help for the insertion in the productive world in a reflective, critical, creative and proactive way. This is made known by the Secretariat of Education of Medellín (2005), in proposing that

Academic management is concerned with the formation on core competences that allow the individual function effectively; the construction of a national identity as a cultural system demand; with the democratic education with values such as solidarity and participation; and with the scientific contributions to the development of science, from a conception of the comprehensive and rigorous knowledge that favors the development of scientific, operational and social skills (p. 15).

According to the Mayor's Office of Medellín (2013) the action of the teacher as mediator of learning and facilitator of the development of competences such as: researcher, promoter and manager in the community environment. In this order of ideas, academicpedagogical management considers: curricular, pedagogical and didactic, integral formation, evaluation, promotion, development and strengthening of the capacities of the teaching staff. In this case, and as signed by Martínez (2012) the pedagogical and academic management is the essence of the work of an educational establishment and is specified in the curriculum, institutional pedagogical practices, development of classes and academic monitoring.

For Martínez (2012), academic management is appreciated as the most important component of the work of an educational institution, since it says and orients the way in which actions and activities should be approached in order to achieve and ensure that students learn and develop the skills necessary for their performance: personal, social and professional. In addition, this area refers to the consolidation, implementation, and management of curricula; the articulation of grades; levels and areas; and classroom work.

The referents for its characterization are the results of the internal and external evaluations, and the basic standards of competence. Opportunities for improvement are created through curricular transversality, the establishment of pedagogical agreements, dialogue between grades, areas and levels, the definition of learning times, the consolidation of an internal evaluation system, the use of results, and the pedagogical use of resources (Martínez, 2012, pp. 19-20).

It is important to point out that, since academic management is the nerve of school task, since the social and cultural responsibilities linked to the school fall more heavily on it, it is necessary to understand the tensions that inhabit the school, the forms that school knowledge assumes when it is subjected to the end of quality, its relations with the curriculum and of course, with the other areas of school management and in particular, the presentations of the knowledge that circulates and is expressed in each one of the actors, teachers and students. It should be made clear that it is not possible to read od describe this area of educational management on its own, it is necessary to relate it to the complexity of the school, the subjects that inhabit it, the affords that compose it, because between these elements there is a mutual interdependence that feeds, energizes and affects them. 


\section{Conclusions}

To approach the school quality demands a dynamic and complex process in which different actors intervene. Due to its cultural and social nature, it does not respond to a unique formula. At the contrary, such process, mutates in every community, region and institution. Thus, the generalization of strategies and methods to achieve it can become in mere intentions that in little or nothing impact the reality of the classrooms. However, there are some lines that, if they are integrated with the particularities of each territory, the school actors and the country context and reference frameworks, may constitute opportunities to travel the horizon of continuous improvement.

The quality processes in educational institutions, as it has been pointed out, are permeated by different factors and protagonists. Therefore, assuming these processes as a permanent task in school, requires to put them into daily discussion. It is urgent to assume the discussion around quality and its management, as an action that, in addition to being permanent, calls out all members of the educational community; Since, as it has been explained, it goes beyond the action of the teacher and school management. It implies that the entire community configures a shared vision of what they want to learn, how they want to do it and in which scenarios they hope to participate with that knowledge.

\section{REFERENCES}

Correa, A., Álvarez, A. y Correa, S. (2010). La gestión Educativa un nuevo paradigma. Medellín: Fundación Universitaria Luis Amigó.

IIPE \& UNESCO. (2000). Modelo de Gestión educativa estratégica. En, Desafíos de la educación: diez módulos destinados a los responsables de los procesos de transformación educativa, Módulo 2 (pp. 15-18). Perú: Ministerio de Educación. Available from https://unesdoc.unesco.org/ark:/48223/pf0000159155

Lusquiños, C. (2005). Gestión educativa: conceptualización y diferenciación de la organización y la administración clásicas. Revista de la Escuela de Ciencias de la Educación, 5(7), 69-85. Available from https://revistas.unc.edu.ar/index.php/pgn/article/ view/15051

Martínez, L. (2012). Administración Educativa. Tlalnepantla: Red Tercer Mileno.

Mayor's Office of Medellín. (2015). Premio Ciudad de Medellín a la Calidad de la Educación 2015. Medellín: Proantioquia. Available from https://www.proantioquia.org.co/ guias-postulacion-premio-medellin/

Mayor's Office of Medellín. (2013). Guía para la postulación de las Instituciones Educativas Oficiales y Privadas al premio a la calidad de la educación. Medellín: Proantioquia. Available from https://www.proantioquia.org.co/desarrollo-educativo/premio-calidada-la-educacion/

Pérez-Ruiz, A. (2014). Enfoques de la gestión escolar: una aproximación desde el contexto latinoamericano. Educación y Educadores, 17(2), 357-369. http://dx.doi.org/10.5294/ edu.2014.17.2.9 
Quality Schools Program. (2010). Modelo de Gestión Educativa Estratégica. [Online]. México, D.F.: Secretaría de Educación Pública. Available from http://formacion.sigeyucatan.gob.mx/formacion/materiales/5/d3/p3/3.\%20EL\%20MODELO\%20DE\%20GESTION\%20EDUCATIVA\%20ESTRATEGICA.pdf

República de Colombia. MEN. (2008). Guía para el mejoramiento institucional. Serie Guías No. 34. Bogotá, D.C.: Cargraphics. Available from https://www.mineducacion. gov.co/1621/articles-177745_archivo_pdf.pdf

Sacristán, J. (2010). ¿Qué significa el currículum? Sinéctica, (34), 21-44. Available from https://sinectica.iteso.mx/index.php/SINECTICA/article/view/144/137

Secretariat of Education of Medellín. (2005). Guía Premios a la Calidad de la Educación. [Online].Medellín: Proantioquia. Available from https://www.proantioquia.org.co/desarrollo-educativo/premio-calidad-a-la-educacion/

UNESCO. (2005). Educación para Todos: EL IMPERATIVO DE LA CALIDAD. Francia: UNESCO Publishing. Available from https://unesdoc.unesco.org/ark:/48223/ pf0000150169 